\title{
BIMBINGAN KONSELING BERPENGARUH TERHADAP AKHLAK SISWA KELAS II PADA MATA PELAJARAN AQIDAH AKHLAK
}

\author{
Tjipto Djuhartono ${ }^{1}$, Bakti Toni Endaryono ${ }^{2}$ \\ Program Studi Pendidian Ekonomi, Universitas Indraprasta PGRI ${ }^{1}$ \\ Program Studi Ekonomi Syariah, Institut Agama Islam Nasional Laa Roiba Bogor ${ }^{2}$ \\ Emil:baktitoni@gmail.com
}

\begin{abstract}
Abstrak
Penelitian ini bertujuan untuk mengetahui Bagaimana Bimbingan Konseling Berpengaruh terhadap Akhlak siswa di SDIT Assalam Kabupaten Bekasi, Metode yang digunakan dalam penelitian ini adalah Metode Kuantitatif dan studi kepustakaan dengan tahap persiapan,pelaksanaan,dan tahap akhir. Teknik pengumpulan data yang dilakukan adalah observasi, wawancara, dan penyebaran kuesioner sejumlah poulasi 20 siswa dengan mengambil populasi tersebut kemudian untuk diteliti. Hasil dari Penelitian ini menunjukan bahwa pertama Pengaruh Bimbingan Konseling terhadap Akhlak Siswa Kelas II di SDIT Assalam adalah sangat baik dari sisi motivasi pelaksanaan pembelajaran dirumah dan memiliki sesuatu yang sangat potensial dalam memacu Akhlak siswa, namun kurang baik dari sisi individu siswa. Kedua dari hasil angket analisa data diketahui bahwa Bimbingan Konseling terhadap Akhlak Siswa Pada Mata Pelajara Aqidah Akhlak Kelas II di SDIT Assalam diperoleh sebesar 52\%. Hasil tersebut menunjukan terdapat hubungan signifikan antara bimbingan konseling dengan akhlak siswa. dan sisanya $48 \%$ dipengaruhi oleh factor lain seperti latar belakang siswa, keluarga dan sebagainya.
\end{abstract}

Kata Kunci ; Pendidikan, Bimbingan Konseling, Ahlak Siswa

\begin{abstract}
This study aims to determine How Counseling Guidance Affects the Morals of Students at SDIT Assalam Bekasi Regency. The method used in this study is the Quantitative Method and literature study with the preparation, implementation, and final stages. The data collection techniques used were observation, interviews, and distributing questionnaires to a population of 20 students by taking the population later for research. The results of this study showed that first, the effect of Counseling Guidance on the Morals of Class II Students at SDIT Assalam was very good in terms of motivation for implementing home learning and had something very potential in spurring students' morals, but not good from the individual side of students. Second, from the results of the data analysis questionnaire, it was known that the Counseling Guidance on the Morals of Students in Class II Aqidah Morals Subjects at SDIT Assalam was obtained by 52\%. These results indicated that there was a significant relationship between counseling guidance and student morals. and the remaining 48\% was influenced by other factors such as student background, family and so on.
\end{abstract}

Key Words : Education, Counseling Guidance, Student Morals

\section{PENDAHULUAN}

Ditahun 2020 negara Indonesia pada bulan Februari mengalami masa sulit di berbagai bidang saat ini khususnya di saat adanya wabah virus Corona atau masa pandemi covid-19 maka peran guru khususnya pada guru bimbingan dan Konseling dewasa ini telah menjadi salah satu pelayanan pendidikan yang sangat dirasakan pentingnya di sekolah-sekolah karena semua aktivitas pembelajaran dilakukan secara online atau daring sehingga semua peserta didik tidak bisa bertatap muka langsung dengan guru.

Kondisi yang terjadi saat ini masalah bimbingan konseling di SDIT Assalam tidak berjalan secara optimal karena guru dimasa pandemi tidak bisa bertatap muka langsung dengan siswa untuk membantu menyelesaikan masalah adapun masalah yang terjadi adalah proses pembelajaran, kurangnya motivasi belajar, bersikap buruk dengan menunda-nunda tugas dan 
keterlambatan akademik sehingga proses pembelajaran yang dilakukan siswa dirumah dilakukan tidak secara benar kondisi ini berpengaruh terhadap mental dan akhlak siswa.

Kondisi yang terjadi diatas maka peran bimbingan konseling sangat di perlukan bagi siswa untuk itu peran guru bimbingan konseling sangat dibutuhkan dengan memiliki beberapa cara dan solusi yang harus dilakukan seperti pendekatan krisis dengan cara bimbingan khusus secara online yang diarahkan secara individu, pendekatan preventif dengan cara pendekatan yang diarahkan khusus untuk mengantisipasi masalah baru muncul, pendekatan perkembangan dengan cara menekanan pengembangan potensi dan kekuatan individu siswa secara optimal dan pendekatan remedial dengan cara bimbingan dengan memfokuskan pada kelemahan siswa dan memberian semangat untuk upaya memperbaikinya.

Solusi dan cara bimbingan konseling tersebut tentunya harus memiliki strategi agar dapat berjalan lancar dan sesuai harapan dimana strategi yang dilakukan adalah melalui bimbingan secara individual, konsultasi, bimbingan kelompok dan belajar bernuasa bimbingan. Bimbingan konseling pada siswa tentunya tidak lepas dari kaidah agama dengan menerapkan nilai moral dan akhlak siswa khususnya dimasa pandemic di era digital saat ini, tantangan bagi guru khususnya di era saat ini perkembangan zaman modern yang begitu pesat khususnya diera digital saat ini diera 4.0 banyak menimbulkan perubahan dalam berbagai aspek kehidupan di masyarakat. Keadaan seperti ini menantang individu khususny peserta didik untuk dapat menyesuaikan diri dengan perubahan dan kemajuan jaman saat ini . Dengan kata lain manusia pada umumnya diharapkan saling memberi bimbingan sesuai dengan kemampuan dan kapasitas manusia itu sendiri, sekaligus memberi konseling agar tetap sabar dan tawakal dalam menghadapi perjalanan kehidupan yang sebenarnya. Hal ini sesuai dengan Al-Qur'an yang menunjukan agar manusia selalu mendidik diri sendiri maupun orang lain, dengan kata lain membimbing ke arah mana seseorang itu akan menjadi baik atau buruk.

Hal ini di jelaskan dalam surat Al-Asr (13) Artinya : Demi masa. Sungguh mereka dalam kerugian, kecuali mereka yang beriman dan melakukan amal kebaikan saling menasehati supaya mengikuti kesabaran dan saling menasehati supaya mengamalkan kesabaran. (Al-Ashr 1-3)

Pelayanan bimbingan dan konseling di sekolah dari tingkat satuan pendidikan sekolah dasar hingga perguruan tinggi, dewasa ini semakin dibutuhkan. Seiring dengan pesatnya perkembangan ilmu Pengetahuan dan Tekhnologi khususnya dimana pandemim covid 19 dan di era digital saat ini diera 4.0, berbagai persoalan pun muncul dengan segala kompleksitasnya. Dunia pendidikan tampaknya belum sepenuhnya mampu menjawab berbagai persoalan akibat perkembangan IPTEK, indikasinya adalah munculnya penyimpangan perilaku yang seyogyanya tidak dilakukan oleh peserta didik khususnya pada peserta didik dengan lebih lama menggunakan handpone untuk bermain game online. Pendidikan dapat berkualitas atau bermutu tinggi apabila sumber daya pendidikan atau faktor-faktor pendidikan cukup memadai. Di antara faktor pendidikan yang perlu terpenuhi kuantitas dan kualitasnya adalah faktor guru.

Berdasarkan permasalahan diatas penelitian ini mendapatkan daya dukung teori dan hasil penelitian sebelumnya yaitu Menurut [1] Secara etimologis bimbingan dan konseling terdiri atas dua kata yaitu " 
Bimbingan" (terjemahan dari kata Guidance ) dan " konseling " (diadopsi dari kata Counseling ) dalam praktik bimbingan dan konseling merupakan satu kesatuan kegiatan yang tidak terpisahkan. Keduanya merupakan bagian yang integral. Menurut [2] Konseling ( counseling ) merupakan bagian integral dari bimbingan. Konseling juga merupakan salah satu tekhnik dalam bimbingan. Konseling merupakn inti dalam bimbingan. Ada yang menyatakan bahwa konseling merupakan " jantungnya " bimbingan sebagai kegiatan inti atau jantungnya bimbingan, praktik bimbingan belum ada apabila tidak dilakukan konseling

Menurut [3] menyatakan bahwa bimbingan disekolah merupakan aspek program pendidikan yang berkenaan dengan bantuan terhadap para siswa agar dapat menyesuaikan diri dengan situasi yang dihadapinya dan merencanakan masa depannya sesuai dengan minat, kemampuan, dan kebutuhan sosialnya. Atau proses bantuan kepada siswa agar ia dapat mengenal dirinya dan dapat memecahkan masalah hidupnya sendiri sehingga ia dapat menikmati hidup secara bahagia (dalam konteks islam bahagia di dunia dan akhirat terutama untuk bimbingan di sekolah).

Menurut [4] Bimbingan dan konseling merupakan salah satu komponen dari pendidikan. Hal ini sangat relevan jika dilihat dari perumusan bahwa pendidikan itu adalah usaha sadar yang bertujuan untuk mengembangkan kepribadian dan potensi-potensi (bakat, minat dan kemampuan). Kepribadian menyangkut masalah perilaku atau sikap mental dan kemampuan meliputi masalah akademik dan keterampilan. Bimbingan dan konseling tidak hanya berorientasi untuk mengatasi permasalahan kesulitan belajar siswa, tetapi bimbingan dan konseling juga dapat menyentuh aspek perilaku atau akhlak siswa dalam proses pembentukan kepribadian. Hasil penelitian menunjukkan bahwa pelaksanaan bimbingan dan konseling di MAN 2 Gresik cukup baik dalam sisi teknik pelaksanaannya, namun kurang baik dalam hasil implementasinya pada individu peserta didik. Hasil angket menunjukkan bimbingan dan konseling sebesar 50\%. Sedangkan akhlak peserta didik di MAN 2 Gresik cukup baik, hal ini bisa dilihat dari angket tentang akhlak peserta didik sebesar $60 \%$. Hasil lain menunjukkan terdapat hubungan yang signifikan antara bimbingan dan konseling terhadap akhlak peserta didik. Dan korelasi bimbingan dan konseling dengan akhlak peserta didik di MAN 2 Gresik diperoleh $46 \%$ dan sisanya 54\% dipengaruhi oleh faktor lain, seperti latar belakang peserta didik, keluarga, lingkungan masyarakat dan sebagainya.

Menurut [5] bahwa rendahnya bimbingan konseling di sekolah disebabkan oleh beberapa rendahnya mutu layanan bimbingan dan konseling di masingmasing sekolah SMP di DKI menguasai dan memiliki kompetensi sebagai bimbingan dan konseling belum sepenuhnya belum sesuai dengan rasio 1:150 siswa; 2) Guru konselor; 3) Guru bimbingan dan konsel ing dengan UndangUndang Nomor 20 tahun 2003 harus dimiliki oleh seorang konselor yang sesuai umumnya belum menguasai pengetahuan yang Pasal 1 ayat (6); dan 4) Guru bimbingan dan konseling masih bertugas rangkaphasil penelitianya.

Menurut [6] bahwa hasil penelitian Problematika dan kepuasan siswa dalam menghadapi pembelajaran jarak jauh di Sekolah Menengah adalah menunjukkan bahwa problematika pembelajaran jarak jauh yang terjadi di SMP Negeri 1 
Pamijahan memperoleh persentase sebesar $58 \%$, sehingga tergolong dalam kategori cukup baik, yang berarti problem yang terjadi tidak begitu serius. Adapun kepuasan siswa dalam pembelajaran jarak jauh memperoleh persentase sebesar $67 \%$, sehingga tergolong dalam kategori cukup puas. Aspek yang perlu dilakukan perbaikan karena masuk dalam kategori tidak baik dalam problematika yaitu aspek pemahaman materi dan interaksi, serta kurang puas pada aspek materi dan metode pembelajaran

Dengan demikian, penulis memandang cukup dengan mendefinisikan Akhlak sesuai ajaran Al-Qur'an dan As-Sunnah. Maka dapatlah penulis katakana bahwa akhlak ialah sejumlah mabda' (prinsip) dan nilai yang mengatur perilaku seorang muslim, yang dibatasi oleh wahyu untuk mengatur kehidupan manusia dan menetapkan pedoman baginya demi merealisasikan tujuan keberadaannya dimuka bumi, yaitu beribadah kepada Allah SWT, untuk meraih kebahagiaan didunia dan akhirat. Jika ilmu akhlak dan ilmu pendidikan akhlak diperhatikan dengan jelas, akan tampak bahwa ruang lingkup pembahasan ilmu akhlak adalah membahas tentang perbuatan-perbuatan manusia, kemudian menetapkannya apakah perbuatan tersebut tergolong perbuatan yang baik atau perbuatan yang buruk. Ilmu akhlak juga dapat disebut sebagai ilmu yang berisi pembahasan dalam upaya mengenal perilaku manusia, kemudian memberikan nilai atau hukum kepada perbuatan tersebut tergolong ke dalam perbuatan baik atau buruk.

\section{METODE}

Metode dalam penelitian ini menggunakan Metode Kuantitatif dan studi kepustakaan dilakukan untuk menyusun landasan teoritik dan penelitian lapangan dengan tahapan persiapan, pelaksanaan dan tahap akhir, tenik pengumpulan data dengan wawancara, observasi, dokumentasi dan menyebarkan angket kuesioner ke 20 siswa kelas 2 Hud . wawancara yang dilakukan adalah secara lansung via online wawancara dengan Nurbaiti S.Pd sebagai wali kelas, Bapak Maulana, S.Pd sebagai guru pelajaran aqidah akhlak pada tanggal 02 februari 2020 serta beberapa orang tua dan murid yang dilakukan secara online melalui media Google meet, observasi yang dilakukan penelitian ini adalah dengan melihat secara langsung sarana dan prasarana penunjang disekolah sebagai lokasi penelitian, dokumentasi yang dilakukan penelitian adalah untuk penunjang data yaitu dengan melihat profil sekolah, brosur sekolah dan buku referensi mata pelajaran aqidah akhlak.

\section{HASIL DAN PEMBAHASAN}

Hasil penelitian berdasarkan wawancara, observasi, dan dokumentasi melalui tahapan penyebaran angket dimana dalam pengisian angket dan lembar pertanyaan yang diberikan oleh peneliti dirangkum dalam beberapa skor atas jawaban responden atas pertanyaan seberapa sering peserta didik melakukan bimbingan konseling pada guru skala type likert.

Siswa pada kelas 2 Hud dengan mata pelajaran aqidah akhlak selalu melakukan bimbingan dengan memililiki skor tertinggi 4, sering malakukan skor 3, kadang dengan skor 2 pernah dengan skor 1 dan paling rendah dengan kategori tidak pernah melalukan bimbingan skor 0 .

Hasil tersebut diatas bahwa dapat dijelaskan hasil rekapitulasi angket yang diberikan kepada siswa kelas 2 Hud sebanyak 20 siswa yaitu hasil angket tertinggi adalah dengan nilai 71 , dengan nilai sedang adalah skor 64 dan nilai skor terendah adalah 58 .

Jumlah hasil perhitungan variable diatas maka untuk memperoleh hasil korelasi 
variable bimbingan konseling dan akhlah adalah angka korelasi variabel $\mathrm{X}$ terhadap variabel Y adalah 2,296. Dengan demikian pengaruh Bimbingan Konseling terhadap akhlak siswa kelas 2 Hud adalah kuat. Uji determinasi adalah Untuk menyatakan besar kecilnya hubungan antara variabel $\mathrm{X}$ terhadap variabel $\mathrm{Y}$, dinyatakan dalam koefisien determinan :

$$
\begin{aligned}
\mathrm{KD} & =(\mathrm{rxy})^{2} \times 100 \% \\
& =(2,296)^{2} \times 100 \% \\
& =5,209=52 \%
\end{aligned}
$$

Perhitungan korelasi antara variable (Bimbingan Konseling) dan variable (Akhlak Siswa) sebesar 5,209 tidak bertanda negative. Angka tersebut jika dipadukan dengan tabel interval korelasi tergolong kuat, maka dengan demikian pengaruh bimbingan konseling terhadap hasil belajar siswa pada mata pelajaran aqidah akhlak tergolong kuat.

Menentukan besar kecilnya pengaruh antara variable $\mathrm{X}$ terhadap variable $\mathrm{Y}$ dinyatakan dengan koefisien determinasi. Hasil perhitungan koefisien determinasi adalah 52\%. Artinya variable yang mempengaruhi akhlak siswa itu salah satunya oleh Bimbingan Konseling yaitu sebesar 48\%. Maka dapat disimpulkan bahwa terdapat pengaruh antara Bimbingan Konseling terhadap akhlak siswa pada mata pelajaran aqidah akhlak pada kelas 2 Hud SDIT Assalam Kabupaten Bekasi.

Berdasarkan Hasil penelitian tersebut bahwa bimbingan konseling yang dilakukan di sekolah tingkat Dasar merupaan salah satu proses bimbingan dalam pembentukan karakter peserta didik khususnya dalam pembentukan akhlak, salah satu tujuan dasar dari bimbingan konseling adalan membentuk perubahan diri pada siswa baik dalam bentuk pandangan, sikap, sifat, maupun keterampilan terutama akhlak yang lebih memungkinkan siswa itu dapat menerima dirinya sendiri, serta pada akhirnya siswa dapat mewujudkan dirinya sendiri secara optimal. Dari pembahasan diatas maka beberapa hasil penelitian menurut [7] Hasil penelitian menunjukkan bahwa terdapat pengaruh yang cukup antara bimbingan dan konseling terhadap pembentukan akhlak siswa. Dengan ditandai bahwa nilai $r$ hitung sebesar 0,517dan termasuk kategori cukup (nilai rhitung pada rentang 0,40-0,599) dengan nilai KD sebesar 27,04 $\%$. Dengan demikian terdapat pengaruh yang cukup signifikan antara bimbingan dan konseling terhadap pembentukan akhlak siswa SMPI Ruhama Cirendeu Ciputat. Bimbingan konseling cukup memberikan kontribusi dalam pembentukan akhlak siswa SMPI Ruhama Cirendeu Ciputat. Dari hasil penelitian terdahulu diatas terdapat kesamaan hasil peneliti saat ini bahwa lebih besar terdapat pengaruh yang signifikan antara bimbingan dan konseling dalam pembentukan akhlak siswa, hasil tersebut tentunya dapat dilakukan dengan langkah-langkah membrikan latihan dan binaan dengan cara melakukan perbuatan baik. Peran guru merupakan sosok penentu bagi keberhasilan proses pembinaan akhlak mulia yang dilakukan di sekolah, yang membimbing dan mengajarkan pengetahuan dan keterampilan kepada siswa hususnya menghadapi tantangan di era digital di masa pandemic saat ini. Oleh karena itu guru dituntut menjadi subjek pendidikan yang mengerti dan faham betul tentang profesi keguruan. Bila dihubungkan dengan pembinaan akhlak mulia atau pendidikan karakter, peran guru sangatlah besar dan penting sebab guru adalah tulang punggung pembinaan akhlak mulia di sekolah hal tersebut dapat tercapai apabila guru khususnya dalam bidang konseling dengan memiliki strategi pembinaan, 
metode pembinaan serta tujuan pembinaan itu sendiri.

Menurut [8] Seorang guru guru tidak hanya menyampaikan ilmu pengetahuan kepada anak didiknya, tetapi juga mendampingi mereka dalam meraih keberhasilan pendidikan. Dalam menjalani setiap aktivitas dalam belajar mengajar ini tugas guru adalah juga memeberikan bimbingan kepada anak didiknya Akan tetapi, anak didik juga membutuhkan bimbingan secara khusus, terutama ketika menghadapi persoalan yang terkait dengan kepribadian, agar dapat menyelesaikan persoalnnya dengan baik. Disinilah sesungguhnya peran keberadaan bimbingan dan konseling di sekolah.

Dari hasil penelitian diatas maka hasil yang didapat penelitian saat ini adalah pentingnya tugas seorang guru dimana guru bimbingan konseling harus melengkapi diri dengan ahlak yang mulia atau karakter yang baik yaitu dengan memiliki ilmu pengetahuan akhlak serta mempraktikkan dalam kehidupan disekolah khususnya di masa pandemic saat ini. Selain itu peran guru pendidikan agama Islam dalam mengajarkan agama kepada siswa dan bertanggung jawab untuk mendidik, mengembangkan ilmu pengetahuan agama dan menanamkan keimanan pada diri siswanya, membimbing kerohanian siswa, menumbuhkan sikap beradab dan menanamkan toleransi antar umat beragama. Untuk itu guru khususnya Pendidikan Agama Islam perlu merealisasikan dengan memberikan pendidikan agama kepada siswa agar ahlak siswa dapat mencerminkan sikap yang beradab dan bermoral yang baik.

Menurut [9] hasil jawaban siswa terhadap angket yang disebar, diketahui bahwa akhlak mulia siswa secara keseluruhan termasuk kategori tinggi (40\%), sedangkan secara per aspek bahwa akhlak mulia siswa menurut kriteria kekuatan ilmu dan kekuatan mengendalikan syahwat adalah berkategori sedang dan kekuatan adil serta kekuatan mengendalikan marah berkategori tinggi.

Menurut [10], Bimbingan dan konseling dalam ranah pendidikan, kedudukannya menjadi bagian dari pendidikan itu sendiri, karena bimbingan dan konseling tujuannya juga dalam rangka membimbing dan mendidik serta membantu individu agar mampu hidup lebih baik. Di samping itu, pendidikan memilik cakupan yang lebih luas dari sekedar bimbingan dan konseling. Oleh sebab itu, sebagai bagian dari pendidikan maka sangat layak jika penggalian konsep makna media bimbingan konseling islam digali dari pengertian media pendidikan itu sendiri.

\section{SIMPULAN}

Berdasarkan hasil penelitian yang penulis lakukan di SDIT Assalam Kabupaten Bekasi tentang Bimbingan Konseling terhadap akhlak siswa pada Mata Pelajaran Akidah Akhlak, maka penulis dapat menarik kesimpulan dari hasil penelitian ini adalah perhitungan angka korelasi dari variabel Bimbingan Konseling terhadap variabel Akhlak siswa pada mata pelajaran akidah akhla sebesar 5,209 bertanda positif dengan hasil Koefisien determinasi sebesar 52\% Angka tersebut jika dikonsultasikan dengan tabel kriteria penilaian, maka pengaruh Bimbingan Konseling terhadap akhlak siswa pada mata pelajaran akidah akhlak tergolong pada kategori kuat dan positif. Untuk menyatakan besar dan kecilnya hubungan antara Bimbingan Konseling terhadap akhlak siswa pada mata pelajaran akidah akhlak dinyatakan dengan koefisien determinasi.. Maka dapat disimpulkan bahwa Bimbingan Konseling berpengaruh terhadap akhlak siswa pada mata pelajaran Aqidah Akhlak. 


\section{DAFTAR PUSTAKA}

[1] Sukardi, Pendekatan Konseling Karir di Dalam Bimbingan Karir. Jakarta: Ghalia Indonesia, 1985.

[2] Tohirin, Bimbingan dan Konseling di Sekolah dan Madrasah. Jakarta: PT Balai Pustaka, 2007.

[3] Hamalik, Proses Belajar Mengajar. Jakarta: PT Bumi Aksara, 2015.

[4] Rofiqoh, "Pengaruh Bimbingan dan Konseling terhadap Akhlak Peserta Didik di MAN 2 Gresik," Digit. Libr. UIN Sunan Ampel, vol. 1, pp. 94165, 2017.

[5] H. Kamaluddin, "Bimbingan dan Konseling Sekolah," J. Pendidik. dan Kebud., vol. 17, no. 4, p. 447, 2011, doi: 10.24832/jpnk.v17i4.40.

[6] Dahlan, S. Zahratusholihah, and K. Nawawi, "Problematika dan Kepuasan Siswa dalam Menghadapi Pembelajaran Jarak Jauh di Sekolah Menengah," SAP (Susunan Artik. Pendidikan), vol. 6, no. 1, 2021, doi: 10.30998/sap.v6i1.9539.
[7] L. Kursila, "Pengaruh Bimbingan dan Konseling terhadap Pembentukan Akhlak Sesama Siswa SMPI Ruhama Cirendeu Ciputat," Institutional Repos. UIN Syarif Hidayatullah Jakarta, 2018.

[8] A. Ridwan, "Peran Guru Agama dalam Bimbingan Konseling," $J$. Pendidik. dan Stud. Islam, vol. Volume 4 N, no. December, pp. 113, 2017, doi: 10.5281/zenodo.3550506.

[9] N. Gustini, "Bimbingan dan Konseling Melalui Pengembangan Akhlak Mulia Siswa Berbasis Pemikiran Al-Ghazali," Tadris J. Kegur. dan Ilmu Tarb., vol. 1, no. 1, pp. 1-14, 2016, [Online]. Available: www.unissula.ac.id.

[10] A. Said Hasan Basri, "Peran Media dalam Layanan Bimbingan," $J$. Dakwah, vol. XI, no. 1, pp. 23-41, 2010. 